\title{
Evaluation of Biocontrol agents against Lasiodiplodia theobromae causing Inflorescence blight of Cashew in Nigeria
}

\author{
Adeniyi D. O., Adedeji, A. R., Oduwaye, O. F. and Kolawole, O. O. \\ Plant Pathology Section, Crop Protection Division, Cocoa Research Institute of Nigeria, \\ P.M.B. 5244, Ibadan, Nigeria
}

\begin{abstract}
Biocontrol agents such as Trichoderma viride and Aspergillus niger hitherto neglected in the control of Lasiodiplodia theobromae causing inflorescence blight disease of cashew were evaluated in-vitro in the mycology laboratory, Plant Pathology Section, Cocoa Research Institute of Nigeria by dual culture technique; pathogen and the bio-agent at equal-distance, pathogen at periphery and pathogen at the centre respectively to determine their antagonistic effects and find out suitable management strategies. The results revealed that the selected bio-agents were able to inhibit the growth of the pathogen's mycelial significantly $(P=0.05)$ A. niger (31.87, 74.74, 80.12\% respectively) and T. viride (25.38, 60.36, 90.48\% respectively) and also reduce the mycelial extension of the pathogen significantly at the adopted dual culture techniques.
\end{abstract}

Keyword: antagonistic potential, bioagents, cashew, culture technique, Inflorescence blight

\section{Introduction}

Cashew (Anacardium occidentale L.) is a tree crop of considerable economic importance in Africa, Asia and Latin America. The tree produces a panicle inflorescence that bears male, female and hermaphrodite flowers [1]. Diseases and deterioration of environmental conditions often occur and result in serious economics losses [2].

Inflorescence blight disease caused by Lasidioplodia theobromae is a major limiting factor affecting cashew nut production in Nigeria, causing $40-45 \%$ crop loss annually [3]; symptoms include withering of petals and other parts of the flower followed by a progressive dieback of the small peduncles from the tips and downward to the main floral shoots. The disease spreads through insects, which create wounds predisposing inflorescence axes to infection.

The pathogen, $L$. theobromae represents the asexual state of Botryosphaeria rhodina (Berk. \& M.A. Curtis) Arx., with a worldwide distribution in tropical and subtropical regions and occurs on a very wide range of plants [4]. Hosts are mainly woody plants including fruit and tree crops. Lasiodiplodia species are common, especially in tropical and subtropical regions where they cause a variety of diseases [5].

Fungicides are still a primary means of controlling diseases; unfortunately some fungicides have lost their effectiveness because of development of resistance by plant pathogens [6]. Perceived negative effects of pesticides on agricultural land, water and soil pollution as well as other health problems have demanded that agricultural scientist pursue alternative controls that are more environmentally friendly, ecologically viable, medically safe and specific for controlling pathogens [7].

Therefore, biological control of plant pathogens has been considered as a potential control strategy in recent years and search for these biological agents is increasing [8].

Alternatively, antifungal agents produced by microorganisms may be use as biocontrol agent [9], as the materials based on microorganisms have properties such as: high specificity against target plant pathogens, easy degradability and low cost of mass production. Biological control offers an important alternative to synthetic chemicals.

Trichoderma is currently the most extensively researched biocontrol fungus and has been shown on a number of occasions to provide a protective effect against some fungi. There are however scarce information on its assessment as a bioagent potential to control inflorescence blight disease of cashew and hitherto for $A$. niger and even in the management of cashew diseases in Nigeria. Past research indicated that Trichoderma can parasitize fungal pathogens and produce antibiotics [10].

Research has been done on biological control potential of Trichoderma spp. against several pathogens attacking vegetables, fruits, field and industrial crops. A. niger has being scarcely used as a bioagent, however research findings has proof its status as a potential bioagent against some fungi.

Considering an array of chemical fungicides and botanicals trials as measures to control inflorescence blight disease of cashew in Nigeria of which appreciable level of successes have been reported, this preliminary investigation was to dive into the trend of global research in eco-friendly crop protection strategies against inflorescence blight disease of cashew as the level of use of antagonistic bio-agents on cashew diseases can not be substantiated in Nigeria. 
The objective of this study was to initiate attempts to identify antagonistic bio-agents against $L$. theobromae the causal organism of cashew inflorescence blight disease in Nigeria.

\section{Materials And Methods}

Lasiodiplodia theobromae was isolated from inflorescences of cashew showing typical symptoms of inflorescence blight disease in Ibadan, Nigeria. It was microscopically identified on the basis of cultural and morphological characters. Pathogenicity of the isolate on cashew inflorescences was determined using the method of [11]. The isolate was maintained on acidified potato dextrose agar (PDA). Colony growth was observed and transferred to obtain pure culture.

Trichoderma viride and Aspergillus niger were tested in-vitro against L. theobromae in the laboratory of Plant Pathology Section, Cocoa Research Institute of Nigeria. The culture discs of $5 \mathrm{~mm}$ in diameter of each of the test organisms and pathogen were cut aseptically from the colony of 6-day and 15-day old pure cultures respectively grown on PDA medium and kept at different positions according to the techniques employed for the study [12].

Culture discs of test organism and the pathogen were placed opposite each other at $4 \mathrm{~cm}$ apart in the petriplate containing 20ml PDA and the antagonistic properties of the test bioagents were exhibited (dual culture technique). Pathogen at the periphery technique had the culture disc of the pathogen placed aseptically $4 \mathrm{~cm}$ away radially from at four corners keeping one disc of the test organism at the centre in the petriplate. The third technique (pathogen at the centre) had the culture disc of the pathogen placed in the centre and four similar discs of the test organism were placed $4 \mathrm{~cm}$ away from the pathogen at the periphery in the petriplate. The culture discs of the pathogen were kept at respective places of pathogen in each technique without bioagents served as control [12].

All treatments were incubated at room temperature $\left(28 \pm 2^{\circ} \mathrm{C}\right)$ and the radial growth of the pathogen was measured after 6 days. There were three replications of the treatments, the percent growth inhibitions (PGI) was calculated as follows:

$\mathrm{PGI}=\frac{\mathrm{dc}-\mathrm{dt}}{\mathrm{dc}} \times 100$

where: Diameter of mycelial colony in control (dc),

Diameter of mycelial colony in treatments (dt),

Percent growth inhibition (PGI)

\section{Results And Discussion}

The antagonists tested in-vitro was significantly superior over control in the three techniques employed against $L$. theobromae. In the dual culture technique, T. viride and A. niger differ significantly with the control, however there was no significantly difference between the test organisms. The percent growth inhibition was higher in A. niger (31.87\%) while that of T. viride was $25.38 \%$, with $52.80 \mathrm{~mm}$ colony diameter of the pathogen in the former while the latter was $57.80 \%$ (table 1 ).

The findings were in harmony with those obtained by [13] which reported T. viride as an active bioagents reducing the radial growth of Fusarium solani by $5.2 \mathrm{~cm}$ and reduced growth percentage by $57.8 \%$. T. viride inhibited significantly highest growth of Colletotrichum gloeosporioide $(15.33 \mathrm{~mm})$ and had percent growth inhibition of $60.69 \%$ [12]. [6] reported T. harzianum, and T. viride exhibited great zone of inhibition in dual culture in-vitro test against $L$. theobromae isolated from banana fruits.

A. niger also had the higher percent growth inhibition of $74.74 \%$ and reduced colony diameter of pathogen to $19.20 \mathrm{~mm}$ which differ significantly from $T$. viride and the control with $30.13 \mathrm{~mm}$ and $76.0 \mathrm{~mm}$ respectively, and $T$. viride had $60.36 \%$ growth inhibition (TABLE 1 ).

This observation shows $A$. niger as more active bioagents strain against $L$. theobromae in pathogen at periphery technique. This differ from the earlier finding of [12], which reported T. viride as a more active bioagents with higher percent growth inhibition over A. niger in the pathogen at periphery test against $C$. gloeosporioide causing anthracnose of Indian bean. [14] in his early findings reported the antagonistic effect of T. viride, T. harzianum and A. niger against $C$. gloeosporioide. 


\section{TABLE}

Table 1: Efficacy of antagonist bioagents against L. theobromae in-vitro

\begin{tabular}{|c|c|c|}
\hline \multicolumn{3}{|c|}{ Pathogen and BCA at equidistant Technique } \\
\hline Trichoderma viride & $57.83 \mathrm{a}^{* *}$ & 25.38 \\
\hline Aspergillus niger & $52.80 \mathrm{a}$ & 31.87 \\
\hline Control & $77.50 \mathrm{~b}$ & 0 \\
\hline LSD & 7.31 & \\
\hline \multicolumn{3}{|c|}{ Pathogen at Periphery Technique } \\
\hline Trichoderma viride & $30.13 \mathrm{~b}$ & 60.36 \\
\hline Aspergillus niger & $19.20 \mathrm{a}$ & 74.74 \\
\hline Control & $76.0 \mathrm{c}$ & 0 \\
\hline LSD & 3.12 & \\
\hline \multicolumn{3}{|c|}{ Pathogen at Centre Technique } \\
\hline Trichoderma viride & $8.0 \mathrm{a}$ & 90.48 \\
\hline Aspergillus niger & $16.7 \mathrm{~b}$ & 80.12 \\
\hline Control & $84.0 \mathrm{c}$ & 0 \\
\hline LSD & 1.37 & \\
\hline
\end{tabular}

*Each value is the mean of three replicates

**Means followed by the same letter in the same column are not significantly different according to LSD (5\%)

[8] also reported T. viride showed maximum inhibition of $71.41 \%$ over control in Rhizoctonia solani (from tomato), and best antagonist inhibiting 67.91 and $66.21 \%$ over control in Sclerotium rolfsii (collar rot of tomato) and Sclerotinia sclerotiorum (web blight of beans) in dual culture test respectively. In the pathogen at the centre technique, $T$. viride treatment had $8.0 \mathrm{~mm}$ pathogen diameter which differ significantly with $A$. niger and control, and had $90.48 \%$ growth inhibition. A. niger also differ significantly from the control reducing pathogen colony to $16.7 \mathrm{~mm}$ (table 1 ).

A. niger, T. viride, T. harzianum, T. longibrachyatum, B. subtilis and P. fluorescence were strong and potent antagonists against $C$. gloeosporioide [15]. It was observed from the study that the antagonists tested by three different techniques were effective against $L$. theobromae and may be of helpful use as potential bioagents.

\section{Conclusion}

Depending on the technique adopted, each of $T$. viride and A. niger proved to be highly antagonistic. However, $A$. niger had a higher antagonistic bioagent potential against $L$. theobromae on cashew inflorescence in two of the three techniques employed in this study. Further researches could unfold exploiting this potential of $A$. niger on many pathogens and managing its adverse effects on crops.

\section{References}

[1]. O. A. Olunloyo, Results of three years spraying of with fungicide-insecticide combinations against Inflorescence dieback disease of cashew. Plant Disease 67, 1983, 1319 - 1320.

[2]. M. Bondad-Reantaso, R.P. Subasinghe, J.R. Arthur, K. Ogawa, S. Chinabut, R. Adlard, Z. Tan and M. Shariff, Disease and health management in Asian aquaculture. Vet. Parasitology, 132, 2005, 249-272.

[3]. O. A. Olunloyo, Efficiency of a simple spray application of fungicide/insecticide combination in the control of Inflorescence blight disease of cashew. Ann. Respt. Cocoa Res. Inst. Nigr. 1979, 64 - 65.

[4]. E. Punithalingam,, Botryodiplodia theobromae. CMI Descriptions of Pathogenic Fungi and Bacteria. No. 519. Kew, Surrey, UK: Commonwealth Mycological Institute, 1976.

[5]. E. Punithalingam, Plant diseases attributed to Botryodiplodia theobromae, in: J. Cramer, Biblioteca Mycologica.( Berlin), 1980

[6]. M. G. Mortuza, and L. L. Ilag, Potential for Biocontrol of Lasiodiplodia theobromae (Pat.) Griff. \& Maubl. in Banana Fruits by Trichoderma species. Biological Control 15, 1999, 235 - 240pp.

[7]. H. Y. El-Kassas, and H. M. Khairy, A Trial for Biological Control of a Pathogenic Fungus (Fusarium solani) by Some Marine Microorganisms by Some Marine Microorganisms. American-Eurasian J. Agric. \& Environ. Sci., 5 (3), $2009,434-440$.

[8]. F. Amin, V.K. Razdan, F. A. Mohiddin, K. A. Bhat, and S. Banday, Potential of Trichoderma Species as Biocontrol agents of soil borne fungal propagules. Journal Of Phytology, 2(10), 2010, 38-41.

[9]. G. S. Chitarra, P. Breeuwer, M. J. R. Nout, A. C. Van Aelst, F. M. Rombouts and T. Abee. An antifungal compound produced by Bacillus subtilis ym10-20 inhibits germination of Penicillium roqueforti conidiospores, J. Appl. Microbiol., 94, $2003,159$.

[10]. N. H. Tran, Using Trichoderma species for Biological control of Plant pathogens in Vietnam. J. Issaas vol. 16(1), 2010, 17-21.

[11]. D. O. Adeniyi, S. B. Orisajo, O. A. Fademi, O. O. Adenuga and L. N. Dongo, Physiological studies of fungi complexes associated with cashew diseases. ARPN Journal of Agricultural and Biological Science. 6(4), 2011. 34 - 38.

[12]. A. J. Deshmukh, B. P. Mehta and V. A. Patil, In vitro Evaluation of some known Bioagents to control Colletotrichum gloeosporioide Penz. And Sacc., causing Anthracnose of Indian bean. International Journal of Pharma and Bio Science, 1(2), 2010, $1-6$.

[13]. E. M. Morsy, K. A. Abdel-kawi and M. N. A. Khalil, 2009. Efficiency of Trichoderma viride and Bacillus subtilis as Biocontrol agents against Fusarium solani on Tomato Plants. Egypt. J. Phytopathol., 37(1), 2009, 47 - 57.

[14]. R. V. Patel, Studies on leaf spot (Colletotrichum gloeosporioide Penz. and Sacc.) of turmeric (Curcuma longa L.) under South Gujarat conditions. M.Sc. (Agri.) Thesis. Gujarat Agricultural University, S. K. Nagar, 2000.

[15]. R. V. Patel, Investigation on dieback and fruit rot (Colletotrichum gloeosporioide Penz. and Sacc.) of chilli (Capsicum annum L.) under South Gujarat condition. M.Sc. (Agri.) Thesis. Gujarat Agricultural University, S. K. Nagar, 2004. 